\title{
Effect of Fertilizer Types on Nutrient Uptake and Yield of Cassava in Ondo Southwestern Nigeria Using Farmers' Simulation Method
}

\author{
Akinbani, A.S.; Ayeni, L.S.
}

\begin{abstract}
Department of Agricultural Science, Adeyemi College of Education, Ondo, Ondo State, Southwestern Nigeria
\end{abstract}

Article No.: 022819040

Type: Research

DOI: 10.15580/GJAS.2019.1.022819040

Submitted: $28 / 02 / 2019$

Accepted: $12 / 03 / 2019$

Published: $30 / 03 / 2019$

${ }^{*}$ Corresponding Author

Dr. Ayeni L.S.

E-mail: leye_sam@yahoo.com

Keywords: Nutrients, tuberisation, agronomic parameters, TMS 419.
Many subsistence farmers find it difficult to apply the right dose of fertilizer using conventional $\mathrm{Kg} / \mathrm{ha}$ or $\mathrm{t} / \mathrm{ha}$ style of recommendation that are normally interpreted to the farmers by the Agricultural Extension Agents. Two field experiments were conducted to determine the effect of fertilizer types on nutrient uptake and yield of cassava using farmer simulation method at Adeyemi College Agricultural Research Farm in Ondo, southwest Nigeria. There were two sites A and B. NPK 15:15:15, Urea, Single Super Phosphate (SSP), Muriate of Potash (MOP), Wood Ash (WA) and Poultry Manure (PM) were used as treatments. Mineral fertilizers were each applied at $300 \mathrm{~kg} / \mathrm{ha}$ using a beer cap as a measure of the treatment while WA and PM were applied at $10 \mathrm{t} / \mathrm{ha}$ using an improvised tin can. There was a control experiment without fertilizer application. The treatments were arranged on Randomized Complete Block Design and replicated three times. Compared with control, NPK, MOP, SSP, Urea, PM and WA significantly increased $(p<0.05)$ plant $N, P$ uptake, cassava root yield and plant growth parameters at both locations. Among the treatments, WA recorded the highest $\mathrm{Ca}, \mathrm{K}, \mathrm{Na}$ and $\mathrm{Mg}$ uptake. All the treatments significantly increased whole tuber weight, peeled tuber weight and tuber length compared with control in location $A$ and $B$. The percentage increase in whole tuber weight in location A was in the order of NPK $(32 \%)>$ WA $(24.45 \%)>$ PM $(21.7 \%)>$ SSP $(5.98 \%)>$ MOP (4.34) > Urea (2.7\%) while the order of increase in tuber weight in location B was PM $(74.4 \%)>$ WA $(74 \%)>$ NPK $(37 \%)>$ SSP $(6 \%)>$ MOP $(4 \%)>$ Urea $(2 \%)$. 


\section{INTRODUCTION}

Many local farmers are of the opinion that cassava can perform well on any type of soil whether fertile or not (Janssens, 2001), even in a depleted soil (Obisesan, 2013). But, the present fertility status of soils in most parts of Nigeria can no longer sustain optimum production of cassava (Adeleye and Ayeni, 2010). They even prefer to grow yams and other arable crops in fertile soils because they believe that cassava can tolerate any type of soils The assertion that cassava will perform well in any type of soil is wrong as the soils of Nigeria are declining very fast in plant nutrients (Ojeniyi, 2008). There is soil degradation and dwindling of the available land needed for growing of arable crops; hence soils are no longer as fertile as they were before. Many farmers also believe that application of mineral fertilizers to cassava may cause tubers deterioration, poor storage, low nutrient quality and increase in puric/hydrocyanic acid; but fertilizer application is unavoidable as a result of nutrients depletion of agricultural soils.

Many subsistence farmers in southwestern Nigeria are not well educated therefore they find it difficult to apply the right dose of fertilizer using conventional $\mathrm{Kg} / \mathrm{ha}$ or $\mathrm{t} / \mathrm{ha}$ style of recommendation that are normally interpreted to the farmers by the Agricultural Extension Agents. For example, a matchbox holds about $25 \mathrm{~g}$ of mineral fertilizer, a teaspoon contains $4 \mathrm{~g}$, a tablespoon $16 \mathrm{~g}$ and a cup holds $250 \mathrm{~g}$. It is better to perform experiments that could fit into farmers' system of farming otherwise there would be no or little adoption of the outcome of the research by farmers. Using farmers' simulation method to perform experiments would reduce the error that might have come up as a result of difference in the method adopted for measurement by the researcher and the farmer field. Using the local method of applying the right dose of fertilizer i.e. tin can, bottle cap, matches etc. would go a long way in alleviating farmers' problems of wrong fertilizer use.

Cassava, one of the main tuberous crops of Nigeria is also a major crop in southern Nigeria (FAO, 1996). The importance of cassava cannot be under estimated if the country wants to achieve its objective in optimum food production. Apart from the fact that it is a staple food consumed by the populace (MoAFS, 2012), it can also be used to feed livestock. Starch can also be derived from it and the leaves that fall from the stems add organic matter to the soil. When fully matured, leaves of cassava plant forms canopy that suppresses weed thereby reducing weeding.

Therefore, it is important to investigate the use of locally sourced organic materials, which are cheap, environmentally friendly and probably have long term effect for improving and sustaining the productivity of soils and arable land. This project work focuses on the use of mineral fertilizers such as CAN, NPK, Phosphate, NPK15:15:15 and their combinations, and organic fertilizers to grow cassava as well as to improve fertility of the soil. The objective of the research is to compare the effect of selected fertilizer types on nutrients uptake growth and tuberisation of cassava.

\section{MATERIALS AND METHOD}

\section{Site Description}

This experiment was conducted at the teaching and research farm, Department of Agricultural Science, Adeyemi College of Education, Ondo, Ondo State. The soil was gently sloppy and coarse in texture. The soil used was typically sandy soil. The site was free from shaded trees and had been previously cultivated. The soil was well drained. Soil samples were taken from $0-20 \mathrm{~cm}$ for nutrients determination before the conduct of the experiments to show the nutrient status of the two locations, soil $\mathrm{pH}$ was determined in 1:2 soil/ $\mathrm{CaCl} 2$., soil OM was determined by the normal dichromate oxidation method (Black, C.A., 1965), total $\mathrm{N}$ was determined by Mickrockjedahl method and available $P$ was determined colourimetrically (Bray and Kurtz, 1945). Exchangeable bases were extracted with $1 \mathrm{M} \mathrm{NH4OAC}$ at $\mathrm{pH}$ 7.0. $\mathrm{Na}$ and $\mathrm{K}$ were determined by flame photometer (Brown and Lilleland, 1958) method while $\mathrm{Ca}$ and $\mathrm{Mg}$ were read with atomic absorption spectrophotometer.

The land was cleared; all roots, stumps and debris were removed. Ridges were made of $5 \mathrm{~m} \times 5 \mathrm{~m}$. There was a discard area of $1 \mathrm{~m}$ apart. The popular varieties of cassava TMS 419 was planted with the stem cutting of $25 \mathrm{~cm}$ length (Odedina et al., 2015) with a spacing of $1 \mathrm{~m} \times 1 \mathrm{~m}$ in slanting position of angle $45^{\circ}$.

The experiment was arranged in a randomized complete block design (RCBD) replicated three times. There were seven treatments namely, wood ash (10t/ha), poultry manure $(10 \mathrm{t} / \mathrm{ha})$, muriate of potash (300kg/ha), NPK 15:15:15 fertilizer (300kg/ha), Single super phosphate fertilizer $(300 \mathrm{~kg} / \mathrm{ha})$, urea fertilizer $(300 \mathrm{~kg} / \mathrm{ha})$ and control. Beer cap was used to apply the mineral fertilizers while tin can was used to apply wood ash and poultry manure into the plots. Poultry manure was cured for two weeks under shade to reduce the toxic effect as a result of heat. Poultry manure and wood ash were applied in ring form two weeks after planting. Cassava spends more than six weeks in soil before maturity, this means, poultry manure would still release enough nutrients to the soil for cassava uptake even without using the conventional method of two weeks before planting.

Two months later urea, NPK, muriate of potash and single superphosphate fertilizers were applied to the base of each of the cassava in ring form on each plot. Cutlass and hoe were used for weeding at three weeks intervals for seven months till the cassava formed a canopy (Pellet et al., 1997).

\section{Data Collection}

Five plants from each plots were randomly selected, tagged and were used for data collection. Data was collected on growth of cassava such as plant 
height, number of leaves, nodes and main branches. Cassava height was measured with a measuring rule while the number of leaves, nodes and main branches were done by visual counting. Whole tuber size and peeled tuber were each weighed with a weighing machine. Tuber length was determined by a measuring rule.

\section{Plant Nutrient Uptake}

Fresh leaves were collected from tagged plants on each plot and transported inside a well labeled paper envelope to the laboratory. The leaves were washed with distilled water, air dried and put inside a hot air oven present to a temperature of $65^{\circ} \mathrm{C}$ for about 24hours and dried to a constant weight. The nutrients determined were $\mathrm{N}, \mathrm{P}, \mathrm{K}, \mathrm{Ca}$ and $\mathrm{Mg}$. Nutrient uptake was analysed from wet digest of the samples (AOAC, 2000).

Statistical Analysis

Data were subjected to analysis of variance and separated by Duncan Multiple Range Test

\section{Result and Discussion}

Table 1 showed the soil properties before the conduct of the experiment. The soil properties showed that the soil was slightly acidic. The soil was deficient in $\mathrm{OM}$, total $\mathrm{N}$ and available $\mathrm{P}$. Potassium $\mathrm{K}, \mathrm{Ca}, \mathrm{Mg}$, $\mathrm{Fe}, \mathrm{Cu}$ and $\mathrm{Zn}$ were adequate for production of cassava in southwestern Nigeria (Adeoye and Agboola, 1985). The OM, N and P status shows that the soil requires additional nutrient from external source for optimum cassava production.

The analysis of the textural class of the soil showed that the soil was sandy loam with high percentage of sand and clay (sand $88.1 \%$, silt $8 \%$ and $3.79 \%$ ). This shows that the soil might be prone to high leaching and erosion that might cause nutrient depletion.
Table 1 Pre-Cropping Soil Chemical Properties

\begin{tabular}{lcc}
\hline $\begin{array}{l}\text { Soil } \\
\text { Properties }\end{array}$ & Location A & Location B \\
\hline $\mathrm{pH}$ & 5.6 & 5.2 \\
$\mathrm{OM}(\%)$ & 2.1 & 1.97 \\
$\mathrm{~N}(\%)$ & 0.12 & 0.1 \\
$\mathrm{P}(\mathrm{mg} \mathrm{kg}-1)$ & 5.79 & 5.67 \\
\multicolumn{2}{l}{ Exchange bases ( C mol kg-1) } \\
$\mathrm{K}$ & 0.17 & 0.15 \\
$\mathrm{Ca}$ & 4.13 & 2.23 \\
$\mathrm{Mg}$ & 1.45 & 1.12 \\
$\mathrm{Na}$ & 1.2 & 1.1 \\
$\mathrm{Micronutrient}$ & $(\mathrm{mg} \mathrm{kg}-1)$ & \\
$\mathrm{Fe}$ & 25.98 & 30.12 \\
$\mathrm{Zn}$ & 5.99 & 6.12 \\
$\mathrm{Cu}$ & 0.6 & 1.2 \\
& & \\
\hline
\end{tabular}

\section{Nutrient Composition of Wood Ash, Poultry Manure, N.P.K, Urea, Murate of Potash and Phosphate Fertilizer}

Table 2 shows the nutrient composition of the wood ash (WA), poultry manure (PM), NPK, Muriate of Potash (MOP), single super phosphate (SSP) and urea fertilizer. Wood ash and poultry manure contained $\mathrm{Ca}$ and $\mathrm{Mg}$ which were not present in NPK, MOP, SSP and urea fertilizers. The assertion that wood ash and poultry manure contain plant nutrients was supported by Belay et al. (2001). Urea had the highest amount of $\mathrm{N}, \mathrm{MOP}$ had the highest $\mathrm{K}$ content while SSP had the highest amount of phosphorus.

Table 2: Nutrient Composition of Wood Ash, Poultry Manure, NPK, urea, Murate of Potash and Phosphate Fertilizer

\begin{tabular}{llllll}
\hline Treatments & \multicolumn{7}{l}{ Nutrient Composition (\%) } & & & \\
\hline & $\mathrm{N}$ & $\mathrm{P}$ & $\mathrm{K}$ & $\mathrm{Ca}$ & $\mathrm{Mg}$ \\
Wood Ash & 0.2 & 1.53 & 2.69 & 14.2 & 2.67 \\
PM & 3.5 & 1.78 & 1.2 & 1.21 & 2.15 \\
NPK & 15 & 15 & 15 & - & - \\
MOP & - & - & 60 & - & - \\
SSP & & 20 & & & - \\
Urea & 46 & - & - & - & - \\
\hline
\end{tabular}

\section{Effect of Fertilizer Types on Nutrient Uptake of Cassava}

The data in Table 5 shows the effect of fertilizer types on nutrient uptake by cassava in location A. Relative to control, all the treatments significantly increased
$(\mathrm{P}<0.05)$ plant $\mathrm{N}$ except MOP and SSP. Relative to control, PM, NPK and SSP significantly increased plant $P$ relative to control. Wood ash, PM, NPK and SSP significantly increased plant $\mathrm{K}$. It was observed that only WA and PM significantly increased plant Mg and $\mathrm{Ca}$. 
Table 3: Effect of Fertilizer Types on Nutrient Uptake of Cassava in location A

\begin{tabular}{lllllll}
\hline Treatments & $\mathbf{N}$ & $\mathbf{P}$ & $\mathbf{K}$ & $\mathbf{C a}$ & $\mathbf{M g}$ & $\mathbf{N a}$ \\
\hline Control & $0.58^{\mathrm{b}}$ & $0.14^{\mathrm{c}}$ & $0.34^{\mathrm{b}}$ & $0.10^{\mathrm{c}}$ & $0.34^{\mathrm{b}}$ & $0.03^{\mathrm{b}}$ \\
WA & $0.79^{\mathrm{b}}$ & $0.23^{\mathrm{b}}$ & $2.87^{\mathrm{a}}$ & $1.67^{\mathrm{a}}$ & $1.13^{\mathrm{a}}$ & $0.17^{\mathrm{a}}$ \\
PM & $0.92^{\mathrm{ab}}$ & $0.45^{\mathrm{a}}$ & $2.77^{\mathrm{a}}$ & $1.48^{\mathrm{a}}$ & $1.02^{\mathrm{a}}$ & $0.09^{\mathrm{b}}$ \\
NPK & $1.09^{\mathrm{a}}$ & $0.47^{\mathrm{a}}$ & $2.89^{\mathrm{a}}$ & $0.71^{\mathrm{b}}$ & $0.44^{\mathrm{b}}$ & $0.03^{\mathrm{b}}$ \\
Urea & $1.29^{\mathrm{a}}$ & $0.18^{\mathrm{c}}$ & $2.15^{\mathrm{b}}$ & $0.09^{\mathrm{c}}$ & $0.37^{\mathrm{b}}$ & $0.03^{\mathrm{b}}$ \\
MOP & $0.46^{\mathrm{b}}$ & $0.19^{\mathrm{c}}$ & $3.93^{\mathrm{a}}$ & $0.11^{\mathrm{c}}$ & $0.33^{\mathrm{b}}$ & $0.05^{\mathrm{b}}$ \\
SSP & $0.59^{\mathrm{b}}$ & $0.89^{\mathrm{a}}$ & $2.36^{\mathrm{a}}$ & 0.08 & $0.36^{\mathrm{b}}$ & $0.06^{\mathrm{b}}$ \\
\hline
\end{tabular}

Means with the same letter are not significantly different using Duncan Multiple Range Test

In location B, compared with control, NPK, Urea, WA and PM significantly increased plant $\mathrm{N}$ Table 4. The cassava plants that were fertilized with SSP, NPK, PM and WA significantly increased plant $P$ relative to control. The $\mathrm{K}$ content in cassava leaves was significant in WA, PM NPK and MOP. The Ca content in cassava leaves was significant in the plants that were treated with WA, PM, MOP and SSP relative to control while $\mathrm{Na}$ was only significant in WA and PM Table 4.

Table 4: Effect of fertilizer types on nutrient uptake of cassava in Location B

\begin{tabular}{lllllll}
\hline Treatment & $\mathbf{N}$ & $\mathbf{P}$ & $\mathbf{K}$ & $\mathbf{C a}$ & $\mathbf{M g}$ & $\mathbf{N a}$ \\
& $\%$ & & & & & \\
\hline Control & $0.32 \mathrm{~b}$ & $0.12 \mathrm{~b}$ & $0.30 \mathrm{~b}$ & $.04 \mathrm{c}$ & $0.33 \mathrm{~b}$ & $0.03 \mathrm{~b}$ \\
WA & $0.69 \mathrm{a}$ & $0.39 \mathrm{a}$ & $1.92 \mathrm{a}$ & $1.92 \mathrm{a}$ & $1.11 \mathrm{a}$ & $0.39 \mathrm{a}$ \\
PM & $0.69 \mathrm{a}$ & $0.49 \mathrm{a}$ & $1.82 \mathrm{a}$ & $1.82 \mathrm{aa}$ & $1.32 \mathrm{a}$ & $0.41 \mathrm{a}$ \\
NPK & $0.78 \mathrm{a}$ & $0.45 \mathrm{a}$ & $1.90 \mathrm{a}$ & $1.90 \mathrm{a}$ & $0.47 \mathrm{~b}$ & $0.05 \mathrm{~b}$ \\
Urea & $0.99 \mathrm{a}$ & $0.18 \mathrm{~b}$ & $0.42 \mathrm{bb}$ & $0.42 \mathrm{~b}$ & $0.42 \mathrm{~b}$ & $0.03 \mathrm{~b}$ \\
MOP & $0.37 \mathrm{~b}$ & $0.16 \mathrm{~b}$ & $1.89 \mathrm{a}$ & $1.89 \mathrm{a}$ & $0.39 \mathrm{~b}$ & $0.07 \mathrm{~b}$ \\
SSP & $0.38 \mathrm{~b}$ & $0.49 \mathrm{a}$ & $0.41 \mathrm{~b}$ & $0.41 \mathrm{~b}$ & $0.32 \mathrm{~b}$ & $0.07 \mathrm{~b}$
\end{tabular}

Means with the same letter are not significantly different using Duncan Multiple Range Test. Table 5 below showed the agronomic parameters of fertilizer treatments, MOP recorded the least plant cassava fertilized with mineral and organic fertilizers. NPK 15:15:15 fertilizer recorded the highest increase in plant height, number of node, number of main height, number of nodes, number of leaves and number of plantable stems while SSP recorded the least number of leaves. branches and number of plantable stems. Among the

Table 5: Effect of Fertilizer types on growth parameters and planting materials of cassava in location A

\begin{tabular}{|c|c|c|c|c|c|c|}
\hline Treatment & $\begin{array}{l}\text { Plant height } \\
\text { ( cm) }\end{array}$ & $\begin{array}{l}\text { No. of } \\
\text { nodes } \\
\text { /plant }\end{array}$ & $\begin{array}{l}\text { No of } \\
\text { leaves } \\
\text { /plants }\end{array}$ & $\begin{array}{l}\text { No of main } \\
\text { branches/ } \\
\text { plant }\end{array}$ & $\begin{array}{l}\text { No of } \\
\text { plantable } \\
\text { stem/ } \\
\text { Plant } \\
(25 \mathrm{~cm})\end{array}$ & $\begin{array}{l}\text { No of } \\
\text { nodes/ } \\
\text { Plantable } \\
\text { stem } 25 \mathrm{~cm}\end{array}$ \\
\hline
\end{tabular}

\begin{tabular}{lllllll}
\hline Control & $120 \mathrm{~b}$ & $104.6 \mathrm{~d}$ & $183.6 \mathrm{a}$ & $3.0 \mathrm{a}$ & $3.0 \mathrm{~b}$ & $8 \mathrm{c}$ \\
WA & $196 \mathrm{a}$ & $266.3 \mathrm{~b}$ & $117.3 \mathrm{c}$ & $4.6 \mathrm{a}$ & $9.44 \mathrm{a}$ & $16 \mathrm{a}$ \\
PM & $195 \mathrm{a}$ & $226.6 \mathrm{c}$ & $84.3 \mathrm{~d}$ & $5.0 \mathrm{a}$ & $8.0 \mathrm{ab}$ & $13 \mathrm{~b}$ \\
NPK & $210 \mathrm{a}$ & $310.0 \mathrm{a}$ & $156.6 \mathrm{~b}$ & $5.3 \mathrm{a}$ & $11.2 \mathrm{a}$ & $20 \mathrm{a}$ \\
Urea & $180 \mathrm{a}$ & $262 \mathrm{~b}$ & $156.6 \mathrm{~b}$ & $5.0 \mathrm{a}$ & $9.8 \mathrm{a}$ & $18 \mathrm{a}$ \\
MOP & $100 \mathrm{~b}$ & $111.6 \mathrm{~d}$ & $47.6 \mathrm{e}$ & $3.6 \mathrm{a}$ & $3.8 \mathrm{~b}$ & $8 \mathrm{c}$ \\
SSP & $133 \mathrm{ab}$ & $305 \mathrm{a}$ & $15.6 \mathrm{f}$ & $3.3 \mathrm{a}$ & $8.2 \mathrm{a}$ & $17 \mathrm{a}$
\end{tabular}

Means with the same letter are not significantly different using Duncan Multiple Range Test. 
In location B, compared with control, all the treatments significantly increased plant height Table 6. Wood ash, PM. NPK Urea and SSP significantly increased nodes in cassava stem. The number of plantable cuttings were significant in fertilized PM, NPK, Urea and MOP Table 6. All the treatments were significantly higher than the control in the number of nodes in plantable cuttings.

Table 6: Effect of Fertilizer types on growth parameters and planting materials of cassava in location B

\begin{tabular}{|c|c|c|c|c|c|c|}
\hline Treatment & $\begin{array}{l}\text { Plant } \\
\text { height } \\
\text { (cm) }\end{array}$ & $\begin{array}{l}\text { No. of } \\
\text { nodes/ } \\
\text { Plant }\end{array}$ & $\begin{array}{l}\text { No of } \\
\text { leaves/ } \\
\text { plants }\end{array}$ & $\begin{array}{l}\text { No of } \\
\text { main } \\
\text { branches/ } \\
\text { plant }\end{array}$ & $\begin{array}{l}\text { No of stem } \\
\text { cutting/ } \\
\text { Plant }\end{array}$ & $\begin{array}{l}\text { No of nodes/ } \\
\text { Cutting }\end{array}$ \\
\hline
\end{tabular}

\begin{tabular}{lllllll}
\hline Control & $\mathbf{7 2 . 0 d}$ & $95 \mathrm{~b}$ & $\mathbf{2 5 b}$ & $4.1 \mathrm{a}$ & $7 \mathrm{~b}$ & $7 \mathrm{c}$ \\
WA & $126.3 \mathrm{~b}$ & $103 \mathrm{a}$ & $62 \mathrm{a}$ & $6.3 \mathrm{a}$ & $9 \mathrm{~b}$ & $13 \mathrm{a}$ \\
PM & $134.3 \mathrm{~b}$ & $114 \mathrm{a}$ & $62 \mathrm{a}$ & $6.4 \mathrm{a}$ & $15 \mathrm{a}$ & $14 \mathrm{a}$ \\
NPK & $176.3 \mathrm{a}$ & $115 \mathrm{a}$ & $68 \mathrm{a}$ & $6.4 \mathrm{a}$ & $15 \mathrm{a}$ & $14 \mathrm{a}$ \\
Urea & $161.3 \mathrm{a}$ & $101 \mathrm{a}$ & $67 \mathrm{a}$ & $4.3 \mathrm{a}$ & $17 \mathrm{a}$ & $10 \mathrm{ab}$ \\
MOP & $114.3 \mathrm{c}$ & $99 \mathrm{~b}$ & $30 \mathrm{~b}$ & $3.2 \mathrm{a}$ & $15 \mathrm{a}$ & $10 \mathrm{ab}$ \\
SSP & $100.0 \mathrm{c}$ & $97 \mathrm{ab}$ & $37 \mathrm{~b}$ & $5.1 \mathrm{a}$ & $10 \mathrm{a}$ & $15 \mathrm{a}$
\end{tabular}

Means with the same letter are not significantly different using Duncan Multiple Range Test

In Location A, compared with control, all the treatments significantly increased fresh tuber weight, tuber length and peeled tuber weight (Table 7 ). Among the fertilizer treatments, NPK recorded the highest cassava whole tuber, weight of peeled cassava tuber and tuber length. The increase in whole tuber were $\mathrm{NPK}>\mathrm{WA}>\mathrm{PM}>\mathrm{MOP}>\mathrm{SSP}>\mathrm{Urea}$.

Table 7: Effect of Fertilizer types on Yield of Cassava location A

\begin{tabular}{llllll}
\hline Treatment & $\begin{array}{l}\text { Whole tuber } \\
\text { weight } / \text { ha }\end{array}$ & $\begin{array}{l}\text { Weight } \\
\text { peeled } \\
\text { cassava } \\
\text { tuber/ha }\end{array}$ & $\begin{array}{l}\text { \%increase } \\
\text { of whole } \\
\text { tuber } \\
\text { cassava }\end{array}$ & $\begin{array}{l}\text { Tuber } \\
\text { length } \\
\text { (cm) }\end{array}$ \\
\hline Control & $18.4 \mathrm{c}$ & $15.64 \mathrm{c}$ & - & $9.81 \mathrm{c}$ \\
WA & $22.9 \mathrm{~b}$ & $19.44 \mathrm{~b}$ & 24.45 & $26.93 \mathrm{a}$ \\
PM & $22.2 \mathrm{~b}$ & $18.87 \mathrm{~b}$ & 21.7 & $22.52 \mathrm{a}$ \\
NPK & $24.3 \mathrm{a}$ & $20.64 \mathrm{a}$ & 32 & $32.51 \mathrm{a}$ \\
Urea & $18.9 \mathrm{c}$ & $16.06 \mathrm{c}$ & 2.7 & $17.77 \mathrm{~b}$ \\
MOP & $19.2 \mathrm{c}$ & $16.32 \mathrm{c}$ & 14,34 & $20.15 \mathrm{ab}$ \\
SSP & $19.5 \mathrm{c}$ & $16.57 \mathrm{c}$ & 5.98 & $15.43 \mathrm{~b}$
\end{tabular}

Means with the same letter are not significantly different using Duncan Multiple Range Test

In location B, compared with control, WA, PM and NPK significantly increased cassava whole tubers and peeled tubers relative to control. The percentage increase in whole tuber weight were in the order PM
$(74.4 \%)>$ WA $\quad(74 \%)>N P K \quad(37)>S S P \quad(6 \%)>M O P$ $(4 \%)>$ Urea $(2 \%)$. All the treatments significantly increased length of cassava tuber. 
Table 8: Effect of fertilizer types on yield of cassava in location B

$\begin{array}{llllll}\text { Treatment } & \begin{array}{l}\text { whole } \\ \text { tuber/ha }\end{array} & \begin{array}{l}\text { peeled } \\ \text { tuber/ha }\end{array} & \begin{array}{l}\% \\ \text { in Increase } \\ \text { tuber }\end{array} & \text { tuber } \\ & & & \end{array}$

\begin{tabular}{lllll}
\hline Control & $10.12 \mathrm{c}$ & $8.24 \mathrm{~b}$ & & - \\
WA & $17.61 \mathrm{a}$ & $13.27 \mathrm{a}$ & 74 & $16.24 \mathrm{c}$ \\
PM & $17.00 \mathrm{a}$ & $14.12 \mathrm{a}$ & 74.4 & $30.42 \mathrm{a}$ \\
NPK & $14.00 \mathrm{~b}$ & $12.00 \mathrm{~b}$ & 37 & $26.12 \mathrm{a}$ \\
Urea & $10.32 \mathrm{c}$ & $8.76 \mathrm{~b}$ & 2 & $20.14 \mathrm{~b}$ \\
MOP & $10.50 \mathrm{c}$ & $8.93 \mathrm{~b}$ & 4 & $21.12 \mathrm{~b}$ \\
SSP & $10.70 \mathrm{c}$ & $9.12 \mathrm{~b}$ & 6 & $37.4 \mathrm{a}$
\end{tabular}

Means with the same letter are not significantly different using Duncan Multiple Range Test

\section{DISCUSSION}

The deficient in OM, N and $P$ of the soil used in the conduct of the experiments in locations $A$ and $B$ shows that the soil required additional nutrients from external source for optimum cassava production. This result on soil fertility is in line with the assertion of Agbede et al., (2008), who observed that most of the soils in southwestern Nigeria are low in plant nutrients. The high percentage of sand in the two locations indicates that they might be prone to erosion, leading to deficiency in major nutrients especially the cations beyond the cassava root zone. It was observed that wood ash and poultry manure contained $\mathrm{Ca}, \mathrm{Mg}$ and $\mathrm{Na}$ which were not present in all the mineral fertilizers used in this research. The plants treated with WA and PM might supply more nutrients in proper balance that are needed for optimum production of cassava than the mineral fertilizers that contained either one or two of the nutrients required for cassava production. Excess of $\mathrm{N}$ in urea, $\mathrm{P}$ in SSP, and $\mathrm{K}$ in MOP might cause nutrient antagonism especially in location $A$ leading to nutrients imbalance which might negatively affect crop production. It was observed that the leaves of cassava absorbed more $\mathrm{N}$ in the plants treated with urea, more $\mathrm{P}$ in the plants treated with SSP and more $\mathrm{K}$ in the soil fertilized with MOP. Also, the plant grown with WA recorded the highest $\mathrm{Ca}$ and $\mathrm{Mg}$. This shows that cassava plants absorb the nutrients readily available to them. It was also observed that all the treatments recorded $\mathrm{P}$ uptake than the control despite the fact that MOP and urea contain no $P$ in their formulation. This might be as a result of the ability of cassava fibrous to absorb $\mathrm{P}$ through myccorhization. This assertion agrees with Leo and Vernon's (2015) statement that, cassava's fibrous roots usually become infected with native soil mycorrhiza, thus resulting in hyphae formation which help in the uptake and transport of $\mathrm{P}$ to the cassava roots.

The better increase in tuber yield of cassava in soil treated with fertilizers input than the control in the two locations might be as a result of nutrients supplied by the fertilizers. The better performance of NPK 15:15:15 fertilizer in increasing tuber weight than the other mineral fertilizers might be the presence of $\mathrm{N}, \mathrm{P}$ and $\mathrm{K}$ in the fertilizer which are primary nutrients that enhance good crop performance. Increase in cassava yield in the soils fertilized with NPK fertilizer is in line with Kamaraj et al. (2008) who reported increase in yield of cassava when NPK fertilizer was applied. The wood ash and PM performed favourably with NPK fertilizer in terms of tuber weight and tuber length.

It was observed in this experiment that there was a sharp difference between location $A$ and $B$ in cassava yield. NPK had the highest increase in cassava tuber yield especially the whole tuber weight and the peeled tuber weight in location $A$ while WA and PM recorded the highest yield in location $B$ this might be as a result of the difference in nutrient status of the two locations. Calcium was high in initial soil of location A while it was low in location B. Cassava plants in location $\mathrm{B}$ absorbed more $\mathrm{Ca}$ and $\mathrm{Mg}$ than any of the nutrient elements used as parameters in this study. Calcium is known to enhance tuberisation while $\mathrm{Mg}$ is known to take part in chlorophyll formation. Though there was low yield of cassava in location B yet the percentage increase in whole cassava tuber indicates that WA and PM perform better than NPK fertilizer. The $\mathrm{Ca}$ and $\mathrm{Mg}$ content present in WA and PM might have compensated for the low soil $\mathrm{Ca}$ and $\mathrm{Mg}$ of location B. The high tuber yield recorded in cassava fertilized with NPK fertilizer in location A might be the N, P and $\mathrm{K}$ present in NPK fertilizer coupled with inherent $\mathrm{Ca}$ from the soil because NPK 15: 15: 15 fertilizer has no $\mathrm{Ca}$ and $\mathrm{Mg}$ in its composition. Ayeni et al., (2010) showed that WA and PM have $\mathrm{Ca}, \mathrm{Mg}$ and micronutrients which are not present in industrially manufactured NPK fertilizers. The better performance of poultry manure and wood ash might be as a result of slow release of nutrients that meet the vegetative and reproductive cycle of cassava. Organic manures normally mineralise late than mineral fertilisers which 
are quicker in mineralization in plant nutrients than organic wastes. These experiments show that crops up to six months to one year are expected to benefit from organic manures than mineral fertilisers.

\section{CONCLUSION}

Investigation into the use of wood ash, poultry manure, single superphosphate and muriate of potash for cassava production was carried out in Ondo Southwestern Nigeria. The result form the two locations showed that poultry manure and wood ash respond well in the soil that is not fertile.

\section{ACKNOWLEDGEMENT}

The authors acknowledge the Tertiary Education Trust Fund (TETFUND) and the Management of Adeyemi College of Education for providing fund for this research.

\section{REFERENCES}

Adeleye, E.O. and Ayeni, L.S. (2010). Effect of cocoa pod ash and poultry manure combinations on soil and plant nutrient contents and performance of maize - screenhouse experiment. Researcher 2 (3): $51-56$..

AOAC (2000). Official methods of analysis. $15^{\text {th }}$ edition. Washington, D. C. Association of Official Analytical Chemists.

Ayeni, L. S. (2010). Effect of combined cocoa pod ash and NPK fertilizer on soil properties, nutrient uptake and yield of maize. Journal of American Science, 6(3): 79-84.

Belay, A., A.S. Classens, F.C. Wehner and J.M. Beer, 2001. Influence of residual manure on selected nutrient elements and microbial composition of soil under long term crop rotation. South Africa J; Plant Soil, 18:1-6.
Black, C.A., 1965. Methods of soil analysis, part 2 American Soci. of Agronomy, INC., Publisher, Madison,Wisconsin, USA.

Bray R. H. and Kurtz, L. T. (1945): Determination of total, organic and available form of phosphorus in soils. Soil Science Society of American Journal 59: $39-45$

Brown, J.D. and Lilleland, 1958. Rapid determination of potassium and sodium in plant material and soil extracts by flame photometry. Proc. Amer. Soc. Hort. Sci., 48: 341-346.

FAO, 1996. Food balance sheets FAOSTAT Database. FAO, Rome.

Janssens M (2001). Cassava. In: Crop Production in Tropical Africa. Raemaekers, $\mathrm{RH}$ (ed). Directorate General for International Cooperation. Brussels. pp. 195-218.

Joy Odedina, Stephen Ojeniyi, Samson Odedina, Thomas Fabunmi, Victor Olowe. 2015. Growth and Yield Responses of Cassava to Poultry Manure and Time of Harvest in Rainforest Agro-Ecological Zone of Nigeria. International Journal of Agricultural Sciences and Natural Resources 2015; 2(3): 67-72

Leo Mathias and Vernon H Kabambe .2015. Potential to increase cassava yields through cattle manure and fertilizer application: Results from Bunda College, Central Malawi. African Journal of Plant Science. 9(5)228 -234

Ministry of Agriculture and Food Security (MoAFS, 2012). Guide to Agriculture Production and Natural Resources Management. Agricultural Communications Branch, Ministry of Agriculture and Food Security, Lilongwe.

Obisesan AA (2013) Credit accessibility and poverty among small cassava farming households in southwest Nigeria. Greener Journal of Agricultural Sciences 3(2): 120-127.

Ojeniyi, S.O. 1980. Nutrient Status of NPK treated Coffee plots. Plants and Soil 56:17-179

Pellet DM, El-Sharkawy MA (1997). Cassava varietal response to fertilization: growth dynamics and implications for cropping sustainability. Exp. Agric. 33:353-365. 